\title{
Membrane Transport across Polarized Epithelia
}

\author{
Maria Daniela Garcia-Castillo, ${ }^{1}$ Daniel J.-F. Chinnapen, ${ }^{1,2,3}$ and Wayne I. Lencer ${ }^{1,2,3}$ \\ ${ }^{1}$ Division of Gastroenterology, Boston Children's Hospital, Boston, Massachusetts 02155 \\ ${ }^{2}$ Department of Pediatrics, Harvard Medical School, Boston, Massachusetts 02155 \\ ${ }^{3}$ Department of Pediatrics, Harvard Digestive Diseases Center, Boston, Massachusetts 02155 \\ Correspondence: wayne.lencer@childrens.harvard.edu
}

Polarized epithelial cells line diverse surfaces throughout the body forming selective barriers between the external environment and the internal milieu. To cross these epithelial barriers, large solutes and other cargoes must undergo transcytosis, an endocytic pathway unique to polarized cell types, and significant for the development of cell polarity, uptake of viral and bacterial pathogens, transepithelial signaling, and immunoglobulin transport. Here, we review recent advances in our knowledge of the transcytotic pathway for proteins and lipids. We also discuss briefly the promise of harnessing the molecules that undergo transcytosis as vehicles for clinical applications in drug delivery.

Ep pithelial cells form delicate but highly effecsingle-cell-thick barriers that define the lumen of many tissues, including all secretory organs and mucosal surfaces. Endothelial cells form analogous single-cell-thick barriers that define blood vessels and capillaries. Both cell types function to separate and affect vastly different physiologic compartments. To achieve these functions, epithelial and endothelial cells must establish and maintain two structurally and functionally different apical and basolateral cell membranes, each interfacing with and affecting only one compartment. Such cell polarity is required to physiologically shape the different environments, in part by driving the vectorial transport of small and large solutes between them. In the case of large solutes, such as the immunoglobulins, albumin, and some signaling molecules, transport can occur only by moving these solutes through the cell via a transcellular endocytic process termed transcytosis (Rojas and Apodaca 2002; Rath et al. 2014; Azizi et al. 2015; Tanigaki et al. 2016). Here, we address new developments in our understanding of transcytosis, the process of endosome trafficking unique to polarized cell types that connects one cell surface with the other. The reader is also referred to the most recent and comprehensive reviews of transcytosis (Rojas and Apodaca 2002; Tuma and Hubbard 2003) and endosome trafficking in polarized cell types (Ang and Folsch 2012; Apodaca et al. 2012; Bay et al. 2015; Folsch 2015).

\section{SPECIALIZATIONS OF ENDOSOMES UNIQUE TO POLARIZED EPITHELIAL CELLS}

The epithelial and endothelial cellular polarity required for barrier function and vectorial transport of peptide and protein solutes is

Editor: Keith E. Mostov

Additional Perspectives on Cell Polarity available at www.cshperspectives.org

Copyright (C) 2017 Cold Spring Harbor Laboratory Press; all rights reserved; doi: 10.1101/cshperspect.a027912

Cite this article as Cold Spring Harb Perspect Biol 2017;9:a027912 
M.D. Garcia-Castillo et al.

achieved in large part by membrane trafficking. Fundamentally, it is membrane trafficking (vesicular transport) that accounts for cell polarity itself (Bryant et al. 2014), by enabling the sorting and delivery of specific membrane proteins and lipids to the appropriate cell surfaces of polarized cells and keeping them there (Mellman 1996; Folsch et al. 2009; Ang and Folsch 2012). Many adaptations of membrane trafficking are required to achieve cell polarity, and the general rules for vesicular transport that define endosome dynamics in nonpolarized cells do not always apply to polarized cell types. Some trafficking proteins, such as Rab11, function differently in polarized cells, and others are uniquely expressed such as AP1 $\mu \mathrm{B}$ (Folsch et al. 1999; Wang et al. 2000b). The transcytotic pathway is a particularly important pathway to understand as the trafficking of membranes and cargoes by this process intersects with all the specialized endosomal compartments adapted by epithelial and endothelial cells to accommodate the polarized cell phenotype (Rojas and Apodaca 2002; Tuma and Hubbard 2003; Ang and Folsch 2012; Apodaca et al. 2012; Bryant et al. 2014; Rodriguez-Boulan and Macara 2014; Bay et al. 2015; Folsch 2015).

Polarized epithelial cells have adapted at least two major specializations of their endosomal compartments. One specialization is the establishment of distinct populations of apical and basolateral early sorting endosomes that receive membranes internalized from only one cell surface and that do not directly interact (Bomsel et al. 1989; Parton et al. 1989; Bomsel et al. 1990; Sheff et al. 2002). The different apical and basolateral sorting endosomes can rapidly recycle internalized components back to the cell surface where endocytosis originated, thus helping to maintain the specialized identity of the apical and basolateral membranes, or they can selectively deliver membrane and cargo to various intracellular compartments shared between them. These shared compartments include the late endosome and lysosome, the Golgi network, the endoplasmic reticulum, and the common/apical recycling endosome. Currently, neither the apical nor basolateral sorting endosomes are thought to sort and deliver cargo directly to the contralateral plasma membrane (basolateral or apical, respectively) to mediate transcytosis (Huber et al. 2000). This is a function of the common endosome (Apodaca et al. 1994; Brown et al. 2000; Mostov et al. 2000).

The common/apical recycling endosome is the other major adaptation of the endosomal network unique to polarized epithelial cells (Parton et al. 1989; Hughson and Hopkins 1990; Apodaca et al. 1994; Barroso and Sztul 1994; Odorizzi et al. 1996; Brown et al. 2000; Mostov et al. 2000). It receives cargo from both apical and basolateral early sorting endosomes and can sort them back to the cell surface where endocytosis originated (recycling), or to the opposite cell surface to enable transcytosis. Although each of the organelles downstream of the early sorting endosomes of polarized epithelia (Golgi, common recycling endosome, lysosome) can transport membrane and cargo to either cell surface (Mellman 1996), the transcytotic pathway appears to originate from the common/apical endosomes. It does not intersect with the retrograde (Golgi and ER) or late endosome/lysosomal pathways (Hoppe et al. 1985; Apodaca et al. 1994; Saslowsky et al. 2013). The basic model for endosome structure and function in polarized (and nonpolarized) cells is shown in Figure 1. To date, many of the features originally proposed in 1994 remain relevant (Apodaca et al. 1994).

\section{Early Apical and Basolateral Sorting Endosomes}

The different early sorting endosomes are located immediately adjacent to the apical or basolateral plasma membrane. They are the first identifiable endocytic compartments after endocytosis, and they are typified by association with Rab5, EEA1, Rab4, Rab11, and transferrin receptor (TfnR) (Goldenring et al. 1996; Sheff et al. 1999; Sonnichsen et al. 2000; Hoekstra et al. 2004; Thompson et al. 2007). Both the apical and basolateral early sorting endosomes receive membrane and cargo from all forms of endocytosis, including clathrin- and non-clathrin-mediated processes (Mayor et al. 2014). Endocytosis by caveolae may predominate in the transcytotic 
A

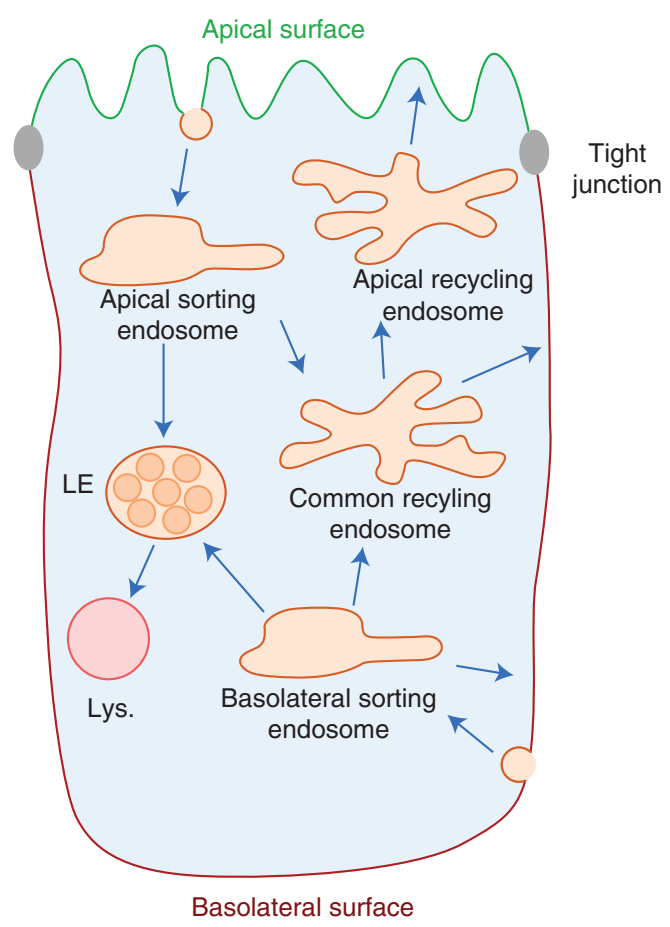

B "Nonpolarized" cell

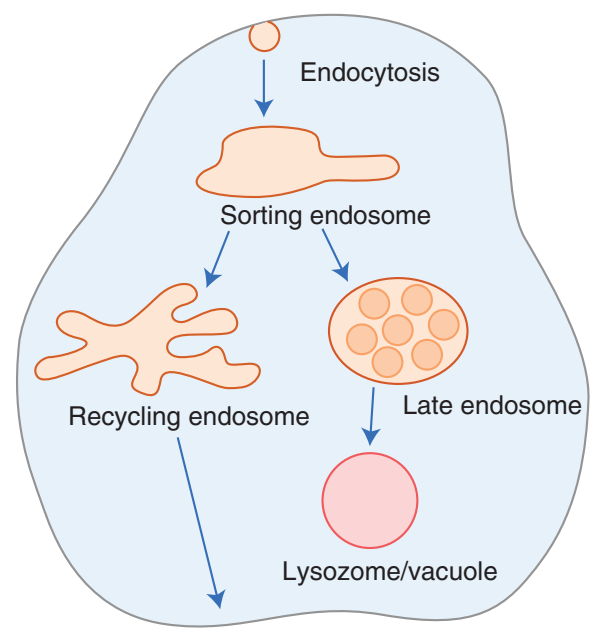

Figure 1. Endosome compartments and pathways. Diagram of pathways across endosomal compartments in $(A)$ polarized epithelial, and $(B)$ nonpolarized cells. Arrows represent transport from one organelle to the next. The apical and basolateral domains are indicated in green and red, respectively.

pathway of endothelial cells (Simionescu and Simionescu 1991; Simionescu et al. 2002; Preston et al. 2014). The early apical and basolateral sorting endosomes mediate recycling. They can also selectively sort membrane and cargo to the lysosome via a process of endosome maturation; or they can sort cargo to the common recycling/apical endosome (Hughson and Hopkins 1990). Sorting to destinations other than the late endosome requires the process of membrane budding and tubulation (Bonifacino and Rojas 2006). Delivery of endocytic cargo to the common/apical recycling endosome appears to be necessary for transcytosis for at least some membrane proteins, such as the immunoglobulin receptors (Apodaca et al. 1994; Tzaban et al. 2009). There are still many features of the early apical and basolateral sorting endosomes that remain unknown. How, for example, do they differ struc- turally or mechanistically, and how do they discern between themselves and apical and basolateral membranes.

\section{Common/Apical Recycling Endosomes}

The common/apical recycling endosome is a separate and stable long-lived structure (Marsh et al. 1995) located in the apical perinuclear region of the cell (Hughson and Hopkins 1990; Apodaca et al. 1994) and dependent on the microtubule cytoskeleton (Bomsel et al. 1990; Breitfield et al. 1990; Hunziker et al. 1990; Apodaca et al. 1994, 2012; Casanova et al. 1999; Hoekstra et al. 2004; Maxfield and McGraw 2004; van Ijzendoorn 2006). It receives membrane and cargo from the different apical and basolateral early sorting endosomes (Hughson and Hopkins 1990; Apodaca et al. 1994; Barroso and Sztul 1994) and also from 
M.D. Garcia-Castillo et al.

the biosynthetic pathway for membrane proteins (Lock and Stow 2005). Like the early sorting endosomes, the common/apical recycling endosome can sort and release cargo to other destinations (Apodaca et al. 1994; Marsh et al. 1995; Tzaban et al. 2009). In this case, it serves as a key site for polarized protein sorting and can selectively traffic membrane and cargo to either cell surface. This was first evidenced by studies on sorting of the polymeric immunoglobulin receptor ( $\mathrm{pIgR}$ ) and transferrin receptor $(\mathrm{TfnR})$. These membrane proteins are internalized from basolateral membranes of polarized epithelia and localize in the common endosome together. However, pIgR is efficiently sorted apically and TfnR basolaterally (Breitfeld et al. 1989; Apodaca et al. 1994; Barroso and Sztul 1994; Gibson et al. 1998). Fluid phase cargo, which typifies the late endosome and lysosomal pathway, also enters the early sorting endosomes, but sorts to the lysosome and does not enter the common endosome. Thus, sorting to the late endosome/lysosome originates primarily from the early sorting endosomes (Apodaca et al. 1994). Established sorting destinations for membrane traffic out of the common/apical endosome of polarized cells include recycling back to the plasma membrane and by transcytosis to the contralateral membrane surface (Apodaca et al. 1994; Tzaban et al. 2009; Goldenring 2015). The mechanics for such selective and polarized sorting of cargo between recycling and transcytosis pathways likely overlaps with the machinery found in the trans-Golgi network (TGN) for the selective and polarized sorting of membrane proteins in the secretory pathway for membrane and secreted proteins of polarized cell types (Gan et al. 2002; Gravotta et al. 2007; Bay et al. 2015).

There is evidence for an additional endocytic compartment located immediately adjacent to the apical membrane, distal to the common endosome in the pathway for delivery of cargo to the apical cell surface, and termed the apical recycling endosome (ARE) (Apodaca et al. 1994; Casanova et al. 1999; van Ijzendoorn and Hoekstra 1999; Leung et al. 2000; Wang et al. 2000a,b; Lapierre et al. 2001; Lapierre and Goldenring 2005). The ARE appears to be dedicated for apically directed recycling and transcytotic cargoes only. The physiologic significance of such a strict apically recycling compartment is emphasized by its ostensive role in regulating cell function, for example, fluid and ion transport across enterocytes (Forte et al. 1990; Casanova et al. 1999; Wang et al. 2000b; Tajika et al. 2004; Swiatecka-Urban et al. 2007); and in the biogenesis and maintenance of the apical membrane of intestinal and liver cells (Wakabayashi et al. 2005; Muller et al. 2008). Other lines of evidence, however, implicate the ARE and its functions as a sorting domain of the common recycling endosome, and not as a separate endocytic compartment (Sheff et al. 1999; Wang et al. 2000a; van Ijzendoorn 2006; Folsch 2008, 2015; Tanos and Rodriguez-Boulan 2008; Weisz and Rodriguez-Boulan 2009; Bay et al. 2015).

\section{THE TRANSCYTOTIC PATHWAY}

\section{Molecular Mechanisms of Transcytosis}

A number of proteins and genes have been implicated in the process of transcytosis, and common elements of the machinery for membrane transport in this pathway have begun to emerge. Here, we summarize the genes recently implicated in the pathway (Table 1).

First, the important roles of clathrin-mediated endocytosis (Hyman et al. 2006; Gravotta et al. 2007; Gonzalez and Rodriguez-Boulan 2009), microtubules (Jaulin et al. 2007; Perez Bay et al. 2013; Yui et al. 2013), myosin/actin (Tzaban et al. 2009), and the small GTPase ARF-6 (Shultz et al. 2006) were further implicated in the process. In MDCK cells (Shmuel et al. 2006), the ARF-6 exchange factor EFA6 was found to regulate apical-to-basolateral transcytosis of IgA (Shultz et al. 2006), possibly acting at the early sorting apical endosome. Knockdown of the Arp2/3 complex in the mouse small intestine caused defective postendocytic vesicular trafficking and impaired transcytosis of IgG (Zhou et al. 2015). Silencing of the human inverted formin 2 (IFN-2) in HepG2 cells resulted in decreased apical sorting and transcytosis of GPI-APs (Madrid et al. 
Membrane Transport across Polarized Epithelia

Table 1. Genes and processes involved in transcytosis (2006-2016)

\begin{tabular}{|c|c|c|c|}
\hline Family & Factors & Function & References \\
\hline $\begin{array}{l}\text { Clathrin } \\
\text { adaptors }\end{array}$ & $A P-1 B$ & $\begin{array}{l}\text { Sorting in the recycling and } \\
\text { biosynthetic routes }\end{array}$ & $\begin{array}{l}\text { Gravotta et al. 2007; reviewed in } \\
\text { Gonzalez and Rodriguez- } \\
\text { Boulan } 2009\end{array}$ \\
\hline Nonclathrin & Naked-2 & $\begin{array}{l}\text { Cargo (TGF- } \alpha \text { ) recognition and } \\
\quad \text { targeting }\end{array}$ & Li et al. 2007 \\
\hline \multirow[t]{3}{*}{ Actin } & EFA6 & $\begin{array}{l}\text { ARF-6 GTPase-activating protein } \\
\text { (GAP)/early endosome } \\
\text { recruitment, regulation of IgA } \\
\text { transcytosis }\end{array}$ & Shultz et al. 2006 \\
\hline & $\begin{array}{l}\text { INF-2 (human } \\
\quad \text { inverted formin 2) }\end{array}$ & $\begin{array}{l}\text { Formation of actin filaments, } \\
\text { regulation of apical transcytosis }\end{array}$ & $\begin{array}{l}\text { Hyman et al. 2006; Madrid et al. } \\
2010\end{array}$ \\
\hline & Myosin $\mathrm{Vb}$ & $\begin{array}{l}\text { Common/apical recycling } \\
\text { endosome }\end{array}$ & $\begin{array}{l}\text { Swiatecka-Urban et al. 2007; } \\
\text { Tzaban et al. 2009; Roland et al. } \\
2011\end{array}$ \\
\hline Microtubules & Kinesin KIF16B & $\begin{array}{l}\text { Tfn and pIgR transcytosis is } \\
\text { microtubule dependent } \\
\text { Common/apical recycling } \\
\text { endosome }\end{array}$ & Perez Bay et al. 2013 \\
\hline \multirow[t]{5}{*}{ Rab GTPases } & Rab11a & Recycling endosome & $\begin{array}{l}\text { Roland et al. 2011; Xu et al. 2011; } \\
\text { Perez Bay et al. 2013; reviewed in } \\
\text { Lapierre et al. } 2012\end{array}$ \\
\hline & $\begin{array}{l}\text { Rab11a family } \\
\quad \text { interacting protein }\end{array}$ & $\begin{array}{l}\text { Rab11 effector, phosphorylation } \\
\text { regulates tight junctions and } \\
\text { transcytosis of Tfn }\end{array}$ & $\begin{array}{l}\text { Ducharme et al. 2007, 2011; } \\
\quad \text { Lapierre et al. } 2012\end{array}$ \\
\hline & TBC1D9B & $\begin{array}{l}\text { Rab11a GAP, regulates IgA } \\
\text { basolateral to apical } \\
\text { transcytosis }\end{array}$ & Gallo et al. 2014 \\
\hline & Rab35 & $\begin{array}{l}\text { Docking of vesicles at apical } \\
\text { plasma membrane and } \\
\text { transcytosis }\end{array}$ & Mrozowska and Fukuda 2016 \\
\hline & Rab25 & $\begin{array}{l}\text { Transcytosis (common/apical } \\
\text { recycling endosome) }\end{array}$ & Tzaban et al. 2009 \\
\hline \multirow[t]{4}{*}{ SNAREs } & Syntaxin-2 & $\begin{array}{l}\text { Interaction with sumyolated } \\
\text { Rab17 }\end{array}$ & Striz and Tuma 2016 \\
\hline & VAMP-7 (Ti-VAMP) & $\begin{array}{l}\text { Required for sorting of apical } \\
\text { proteins and transcytosis }\end{array}$ & Pocard et al. 2007 \\
\hline & $V A M P-8$ & $\begin{array}{l}\text { Transcytosis to the apical } \\
\text { membrane }\end{array}$ & Pocard et al. 2007 \\
\hline & $\begin{array}{l}\text { Phosphoinositide-3 } \\
\text { kinase }\end{array}$ & $\begin{array}{l}\text { Controls retromer's role in pIgR- } \\
\text { pIgA transcytosis }\end{array}$ & Verges et al. 2007 \\
\hline Retromer & & $\begin{array}{l}\text { Sorting of B-secretase in MDCK } \\
\text { cells, TGF- } \beta \text { trafficking and } \\
\text { localization to basolateral } \\
\text { membrane }\end{array}$ & $\begin{array}{l}\text { Cuartero et al. 2012; role of } \\
\text { retromer reviewed in Yin et al. } \\
\text { 2013; Verges } 2016\end{array}$ \\
\hline \multirow[t]{2}{*}{ Lipid rafts } & $\begin{array}{l}\text { MAL (myelin and } \\
\text { lymphocyte } \\
\text { protein) }\end{array}$ & $\begin{array}{l}\text { Raft stabilizer, induces large } \\
\text { clusters containing apical } \\
\text { proteins }\end{array}$ & $\begin{array}{l}\text { de Marco et al. 2002, 2006; } \\
\text { Marazuela et al. 2004; Magal } \\
\text { et al. 2009; In and Tuma 2010; } \\
\text { Ramnarayanan and Tuma 2011 }\end{array}$ \\
\hline & Oligomerization & $\begin{array}{l}\text { Increases GPI-APs affinity to } \\
\text { DRMs and transcytosis to } \\
\text { apical membrane }\end{array}$ & Galmes et al. 2013 \\
\hline
\end{tabular}


M.D. Garcia-Castillo et al.

\begin{tabular}{|c|c|c|c|}
\hline Family & Factors & Function & References \\
\hline & Galectin-4 & $\begin{array}{l}\text { Acts as an apical sorting signal } \\
\text { and mediates TfR transcytosis }\end{array}$ & Perez Bay et al. 2014 \\
\hline \multirow[t]{3}{*}{ Other } & Ceramide & $\begin{array}{l}\text { Transcytosis of oxLDL across the } \\
\text { endothelial cell barrier }\end{array}$ & Li et al. 2014 \\
\hline & $M f_{s} d 2$ & $\begin{array}{l}\text { Required for functional BBB; } \\
\text { major transporter for DHA } \\
\text { (omega-3 fatty acid) uptake } \\
\text { into brain }\end{array}$ & $\begin{array}{l}\text { Ben-Zvi et al. 2014; Nguyen et al. } \\
\text { 2014; Guemez-Gamboa et al. } \\
\text { 2015; Wang et al. } 2016\end{array}$ \\
\hline & Godzilla & $\begin{array}{l}\text { E3-ubiquitin ligase; Wingless } \\
\text { signaling }\end{array}$ & Yamazaki et al. 2016. \\
\hline
\end{tabular}

2010). Cell polarity and apical transcytosis was also confirmed to be strongly dependent on specific microtubule motors (Jaulin et al. 2007; Perez Bay et al. 2013). These results strengthen the evidence for a central role of the actin and microtubule cytoskeletons in sorting cargo through the transcytotic pathway, as true for other endocytic pathways.

Other genes, some already known to be involved in membrane transport and others not, have newly been implicated in transcytosis. These include members of the SNARE fusion machinery-the v-SNAREs VAMP-7 and VAMP-8 - which were found required for polarized sorting and transcytosis of transmembrane proteins and GPI-APs in FRT and $\mathrm{Caco} 2$ cells (Pocard et al. 2007). Another study showed that the plasma membrane-associated SNARE syntaxin-2 and its association with sumoylated Rab17 provides selectivity for syntaxin binding necessary for fusion of transcytotic vesicles at the apical surface (Striz and Tuma 2016). A role for retromer in polarized transport (Verges 2016) and in pIgR-pIgA transcytosis was also confirmed (Verges et al. 2004, 2007). Rab GTPase family members Rab 17, Rab 25, Rab 11, Rab 35, Rab 27 (Tzaban et al. 2009; Xu et al. 2011; Yasuda et al. 2012; Mrozowska and Fukuda 2016; Striz and Tuma 2016) and Rab 11associated FIP family proteins (Ducharme et al. 2007, 2011; Su et al. 2010; Lapierre et al. 2012) were found required for epithelial cell polarization, vesicular transport to the apical plasma membrane, and transcytosis of IgA-pIgR, IgGFcRn, and Tf-TfR. The Drosophilia E3-ligase
Godzilla was discovered to affect Wnt signaling by affecting transepithelial transport of the molecule in the wing imaginal discs (Yamazaki et al. 2016). This gene product has not been previously implicated in membrane trafficking, and how Godzilla or any E3 ligase operates to affect transcytosis remains to be elucidated.

Evidence has also suggested that $\mathrm{N}$-glycans and $\mathrm{O}$-glycans act as lumenal apical sorting signals in transcytosis, perhaps enabled by binding to the galectins such as galectin-3 (Honig et al. 2015) and galectin-4 (Perez Bay et al. 2014). Raft clustering, implicated in the biogenesis of apical membrane domains (Schuck and Simons 2004), may also contribute to transcytosis of GPI-APs (Galmes et al. 2013). The raft-associated protein MAL was found essential for enabling transcytosis of both pIgR and GPI-APs (de Marco et al. 2002, 2006).

Finally, in the context of endothelial cells, the major facilitator superfamily domain-containing protein $2 \mathrm{~A}$ (Mfsd2a) was shown to cause a general down-regulation of transcytosis in brain endothelial cells. Mfsd2a is a $\mathrm{Na}^{+}$-dependent phospholipid transporter. How it operates as a master regulator of transcytosis remains unknown. Nevertheless, the diminished transcytotic pathway caused by expression of this gene in this cell type may in part functionally define the blood-brain barrier (Ben-Zvi et al. 2014).

Overall, a unified model explaining how sorting occurs in the apically and basolaterally directed transcytotic pathways has yet to emerge. Multiple mechanisms adapted to different cargoes and cell types will likely be found. 
Transcytosis of the Immunoglobulins

Transcytosis for various cargoes (Table 2) has been documented in polarized epithelial and endothelial cells, neurons, and osteoclasts. The pathway is probably best studied for the immunoglobulin receptors, especially for IgA/IgM and IgG, which are transported by binding the polymeric immunoglobulin receptor pIgR (Apodaca et al. 1994; Rojas and Apodaca 2002) and the Fc-trafficking receptor FcRn (Baker et al. 2009; Pyzik et al. 2015), respectively (Table 2). In the case of transepithelial IgA transport, pIgR binds dIgA on the basolateral membrane and carries it sequentially into the early basolateral sorting endosome, the common/apical recycling endosome, and finally to the apical cell surface where the extracellular domain of the receptor is cleaved still bound to IgA for release into the lumen as secretory $\operatorname{IgA}(\operatorname{sg} \mathrm{A})$. Many of the regulatory components and structural elements of the pIgR required for this pathway have been well reviewed (Rojas and Apodaca 2002; Apodaca et al. 2012). In contrast to $\mathrm{pIgR}, \mathrm{FcRn}$ traffics immunoglobulin $\mathrm{G}$ ( IgG) in both directions across polarized epithelial cells. Like pIgR, FcRn also traffics IgG through the common/apical recycling endosome (CRE), after which the actin motor myosin $\mathrm{Vb}$ and the GTPase Rab25 regulate a sorting step that specifies transcytosis. But these molecules do not affect the recycling of FcRn, suggesting their involvement in a sorting step specific to the transcytotic pathway (Tzaban et al. 2009). Another regulatory component of the CRE, Rab11a was found to be needed for transcytosis of pIgR (Bryant et al. 2010), but Rab11 was dispensable for transcytosis of FcRn (Tzaban et al. 2009). Thus, the two receptors likely do not use identical machinery for polarized sorting. In the case of FcRn, it appears that the cell can sort the receptor from the endosome to the cell surface via distinct recycling and transcytosis pathways. This model for separate transcyto-

Table 2. Cargoes undergoing transcytosis in polarized epithelia

\begin{tabular}{|c|c|}
\hline Cargo & References \\
\hline \multicolumn{2}{|l|}{ Immunoglubulins } \\
\hline $\operatorname{IgA} / \mathrm{pIgR}$ & Apodaca et al. 1994; Mostov 1994; Verges et al. 2004; Moon et al. 2014 \\
\hline IgG/ FcRn & Claypool et al. 2002; Li et al. 2011 \\
\hline $\operatorname{IgE}$ & Palaniyandi et al. 2015 \\
\hline EGF & Kozu et al. 1997; Maratos-Flier et al. 1987; Brandli et al. 1991 \\
\hline \multicolumn{2}{|l|}{ Endogenous cargoes } \\
\hline Transferrin & $\begin{array}{l}\text { Fishman et al. 1987; Roberts et al. 1993; Skarlatos et al. 1995; Broadwell et al. 1996; } \\
\text { Descamps et al. 1996; Burdo et al. 2003; Du et al. 2013; Manich et al. 2013; Wiley } \\
\text { et al. 2013; }\end{array}$ \\
\hline Insulin & Azizi et al. 2015 \\
\hline DARC & Lee et al. 2003; Pruenster et al. 2009; Novitzky-Basso and Rot 2012; Minten et al. 2014 \\
\hline SorLA & Klinger et al. 2016 \\
\hline LDL & Candela et al. 2008; Bian et al. 2014; Li et al. 2014; Zhang et al. 2014 \\
\hline PI-CALM & Zhao et al. 2015 \\
\hline A1AT & Lockett et al. 2014 \\
\hline HTLV-1 & Martin-Latil et al. 2012 \\
\hline \multicolumn{2}{|c|}{ Viral and bacterial pathogens } \\
\hline P97 & Tang et al. 2007 \\
\hline Botulinum toxin & Maksymowych and Simpson 1998; Ahsan et al. 2005; Miyashita et al. 2014 \\
\hline Listeria monocytegenes & Nikitas et al. 2011 \\
\hline Epstein-Barr virus & Tugizov et al. 2013 \\
\hline HIV & Dohgu et al. 2011; Gupta et al. 2013; Kinlock et al. 2014 \\
\hline Cholera toxin & Lencer et al. 1995; Saslowsky et al. 2013 \\
\hline Shiga toxin & Malyukova et al. 2008, 2009; Lukyanenko et al. 2011 \\
\hline
\end{tabular}


M.D. Garcia-Castillo et al.

sis and recycling pathways is consistent with results of a targeted siRNA screen we recently completed in cultured MDCK epithelial cells for genes involved in transcytosis of FcRn (B Nelms and WI Lencer, unpubl.).

\section{Other Proteins and Cargoes Undergoing Transcytosis}

One of the important physiologic functions of transcytosis is to mediate transepithelial and transendothelial signal transduction. Insulin signaling, for example, requires transcytosis of the peptide hormone across tight endothelial barriers of adipose and muscle tissues, and this appears to require clathrin-dependent, not caveole-dependent, endocytosis (Azizi et al. 2015). Similarly, the Duffy antigen receptor for chemokines (DARC) acts as a trafficking chaperone to promote the transendothelial transport of inflammatory chemokines, including growth-related oncogene- $\alpha / \mathrm{CXC}$ chemokine ligand 1 (GRO- $\alpha /$ CXCL1). This has been shown to be involved in regulating leukocyte migration and the inflammatory response (Lee et al. 2003; Pruenster et al. 2009; Novitzky-Basso and Rot 2012; Minten et al. 2014). The Vps10 family member SorLA, a transmembrane sorting receptor for several ligands including lipoprotein lipase and amyloid precursor protein, was recently found to cross MDCK cells by transcytosis from basolateral to apical membranes. The pathway intersects with the common endosome as measured by colocalization with TfnR and may explain how lipoprotein lipase is secreted into breast milk (Klinger et al. 2016).

In some cases, transcytosis is implicated in the pathogenesis of human disease. Low-density lipoprotein (LDL) transcytosis across endothelial cells, for example, was recently linked to atherosclerosis and shown to be stimulated by C-reactive protein (Candela et al. 2008; Bian et al. 2014; Li et al. 2014; Zhang et al. 2014). Dietary DNA-fragments, even up to a few hundred base pairs, appear able to cross the intestinal barrier via vesicular transport to enter the bloodstream where they may function to regulate the immune system (Johannessen et al. 2013). Transcytosis of phosphatidylinositol- binding clathrin assembly protein (PI-CALM) across the $\mathrm{BBB}$ has a role in brain homeostasis and is implicated in $A \beta$ precursor protein (APP) clearance during Alzheimer's disease (Zhao et al. 2015). The glycoprotein serine protease inhibitor Alpha 1 antitrypsin (A1AT) modulates inflammatory responses in the lung endothelium. A recent report showed in vitro that A1AT is able to cross the lung endothelial barrier for delivery to adjacent epithelial cells from the circulation (Lockett et al. 2014).

Some microbes exploit transcytosis to cause disease (Bomsel 1997; Couesnon et al. 2008). The human T-cell leukemia virus type 1 (HTLV-1), the causative agent of adult T-cell leukemia/lymphoma, is one example of a pathogen that co-opts transcytosis to cross tight epithelial barriers and infect subepithelial dendritic cells (Martin-Latil et al. 2012). In another example, transcytosis of Botulinum toxin across T84-cell monolayers was recently visualized in vitro, confirming previous studies showing botulinum toxin transport across intestinal tissues (Maksymowych and Simpson 1998; Ahsan et al. 2005; Miyashita et al. 2014). Listeria monocytogenes undergoes transcytosis across the intestinal barrier on specific targeting of goblet cell E-cadherin (Nikitas et al. 2011). Epstein-Barr virus (EBV) appears to cross oral epithelial cells bidirectionally (Tugizov et al. 2013), and HIV transport across polarized epithelial cells may depend on IgG and trafficking by FcRn (Dohgu et al. 2011; Gupta et al. 2013; Kinlock et al. 2014). Candida albicans co-opts the transcytotic pathway of $\mathrm{M}$ cells as a portal of entry across the intestinal barrier (Albac et al. 2016). Human melanotransferrin (MTf, also named P97), a transferrin homolog undergoes basolateral to apical transcytosis and directs adeno-associated virus (AAV) transcytosis across the blood-brain barrier (Tang et al. 2007).

\section{Clinical Applications}

Transcytosis of membrane proteins may be harnessed for mucosal and transendothelial delivery of therapeutic peptides and proteins (Spiekermann et al. 2002; Li et al. 2011; Georgieva et al. 2014). Such transport of small molecule 
drugs and larger biologics across polarized mucosal barriers for oral bioavailability is a major hurdle in drug development, and governed in part by the compartmentalized pathway and complex machinery involved in transcytosis (Fan et al. 2016). With the emerging fields of antibody-based therapeutics and oligonucleotide-based gene editing showing great promise, the failure of many biologic drug candidates to reach affected tissues underscores the importance of developing new technologies for drug delivery and for studies that further our understanding of the mechanisms responsible for transcellular transport (Juliano 2016; Parakh et al. 2016; Rabideau and Pentelute 2016).

Typically, large macromolecules either cannot enter the cell efficiently, or are internalized into endosomal compartments destined for lysosomal degradation (Pardridge 2015). Several approaches for drug delivery target endogenous protein receptors located on the apical membranes that enter the transcytotic pathways, such as TfnR, FcRn, and insulin receptor (Lajoie and Shusta 2015; Martins et al. 2016). Here, the major application is to cross the endothelial microvasculature of the blood-brain barrier, with promising examples found with delivery of antibodies for A $\beta$ amyloid (Niewoehner et al. 2014), and for delivering various lysosomal replacement enzymes (Pardridge 2015). For oral delivery via absorption through the intestinal epithelium, however, additional hurdles greatly impede drug delivery, such as the acidic gastric environment, an array of degradative enzymes, and the intestinal mucus layer. Recent advances in nanoparticle technologies can address some of these problems and engage the endocytic machinery via membrane receptors to cross enterocytes or $\mathrm{M}$ cells into the lamina propria (Yu et al. 2016). Overall, in spite of these challenges, it appears the transcytotic pathway of membrane proteins may be successfully exploited to deliver therapeutic molecules across polarized cell barriers.

Lipid Sorting in Polarized Epithelial Cells and Transcytosis

Several viral and bacterial toxins exploit membrane glycosphingolipids to breach epithelial barriers by transcytosis (Lencer et al. 1995; Malyukova et al. 2008). Cholera toxin, for example, is found to traffic from apical to basolateral membranes of intestinal epithelial cells in vitro, and this depends on toxin binding via its Bsubunit to its glycosphingolipid receptor GM1 (Lencer et al. 1995). The ability of cholera toxin to breech epithelial barriers by transcytosis may explain, in part, its well-known effects on mucosal vaccines (Stratmann 2015). The B-subunit of the toxin has the potential to bind up to five GM1 lipids at once, effectively cross-linking them in the plane of the membrane. We recently found that the structure of the ceramide domain of GM1 plays a decisive role in dictating the sorting and trafficking routes of the lipid in both polarized and nonpolarized cell types (Chinnapen et al. 2012; Saslowsky et al. 2013). In nonpolarized epithelial cells, GM1 species with short or unsaturated fatty acids traffic from the sorting endosome to recycling and late endosomes, the TGN, and to the ER, whereas long saturated chain GM1 were mainly found in late endosomes (Chinnapen et al. 2012). On cross-linking these lipids by binding the cholera toxin B-subunit, GM1 trafficking to the ER, and paradoxically also to the lysosome, is enhanced, possibly caused by association with lipid raft microdomains. In polarized cells, GM1 species containing short or unsaturated fatty acid chains traffic across the cell by transcytosis in the absence of toxin binding (Saslowsky et al. 2013). Transcytosis of GM1 does not require trafficking retrograde through the TGN (Saslowsky et al. 2013).

Experimental evidence has similarly implicated lipid sorting in the transcellular transport of Shiga Toxin-1 (Stx1) (Malyukova et al. 2008, 2009; Lukyanenko et al. 2011). Here, Stx1 binds to the globotriasylceramide Gb3 located on the apical outer leaflet of the membrane of host cells, and it is endocytosed by actin- and Srcdependent macropinocytosis. In this case, the B-subunit of Stx can cluster up to 15 Gb3 lipids greatly enhancing its endocytic and trafficking properties and specificities (Karve and Weiss 2014). When Escherichia coli O157/H7 strains that secrete Shiga toxins are allowed to colonize intestinal epithelial cells, shiga toxin is 
M.D. Garcia-Castillo et al.

transported to basolateral membranes presumably via transcytosis of Gb3 lipids (Malyukova et al. 2008; Lukyanenko et al. 2011). Ceramide lipids have also been shown to affect the transcytotic pathway in endothelial cells for transport of oxidated low-density lipoprotein and albumin across the endothelial barrier in vitro and in vivo (Li et al. 2014; Kuebler et al. 2016).

How the cell recognizes and sorts the different ceramide domains of the different sphingolipid species remains unknown. The two major ideas in the field, that of curvature-dependent sorting by molecular shape and/or by association with membrane microdomains of lipid and protein mixtures connected to the membrane cytoskeleton (lipid rafts), or lack thereof, are plausible (Heinrich et al. 2010; Callan-Jones et al. 2011; Diaz-Rohrer et al. 2014). The former hypothesis is a biophysical sorting process, wherein the overall structural topology of the lipid dictates whether they can enter into sharp bends and turns in the early endosomal membrane that are needed to form sorting tubules to traffic to other cellular destinations; in effect, escaping the late endosome/lysosome pathway. The latter sorting mechanism is protein and lipid dependent, in which lateral heterogeneity in the membrane creates nanometer-sized domains of high order, and association with these domains is believed to lead to key signaling events, and connect to the endocytosis and sorting machinery. Glycolipid sorting could also be driven by lectin binding, such as that proposed for the galectins, and in clathrin-independent endocytosis of GM1 (Fajka-Boja et al. 2008; Lakshminarayan et al. 2014). None of these hypotheses are mutually exclusive, and it is believed that some processes may work within each other.

\section{Clinical Applications}

As for membrane proteins, lipid sorting pathways may also be harnessed for the clinical application of drug delivery via transepithelial or transendothelial transport. Our laboratory is currently developing an approach to deliver therapeutic peptides or proteins across a mucosal barrier that takes advantage of glycosphin- golipid trafficking (te Welscher et al. 2014). Using short and unsaturated fatty acid containing GM1 as a trafficking platform, the cargo is covalently attached via the oligosaccharide head group. By fusion of nonnatural species of GM1 to glucagon-like peptide (GLP1), transepithelial transport was observed in vitro and in vivo. Subsequent studies on the structure of the ceramide chain show this approach to be robust (unpubl.). Another approach that coopts endogenous glycosphingolipid trafficking uses a novel peptide that binds GM1 (Stojanov et al. 2012). When injected systemically, this peptide breeches the endothelial blood-brain barrier by transcytosis. In principle, both protein- and lipid-dependent trafficking across tight epithelial and endothelial barriers show promise for diverse clinical applications.

\section{ACKNOWLEDGMENTS}

We acknowledge the following funding sources: DK048106, DK0484424, and the Harvard Digestive Diseases Center DK034854. We also thank members of the Lencer laboratory for careful reading of the manuscript and for many helpful comments.

\section{REFERENCES}

Ahsan CR, Hajnoczky G, Maksymowych AB, Simpson LL. 2005. Visualization of binding and transcytosis of botulinum toxin by human intestinal epithelial cells. J Pharmacol Exp Therapeut 315: 1028-1035.

Albac S, Schmitz A, Lopez-Alayon C, d'Enfert C, Sautour M, Ducreux A, Labruere-Chazal C, Laue M, Holland G, Bonnin A, et al. 2016. Candida albicans is able to use M cells as a portal of entry across the intestinal barrier in vitro. Cell Microbiol 18: 195-210.

Ang SF, Folsch H. 2012. The role of secretory and endocytic pathways in the maintenance of cell polarity. Essays Biochem 53: 29-39.

Apodaca G, Katz LA, Mostov KE. 1994. Receptor-mediated transcytosis of IgA in MDCK cells is via apical recycling endosomes. J Cell Biol 125: 67-86.

Apodaca G, Gallo LI, Bryant DM. 2012. Role of membrane traffic in the generation of epithelial cell asymmetry. Nat Cell Biol 14: 1235-1243.

Azizi PM, Zyla RE, Guan S, Wang C, Liu J, Bolz SS, Heit B, Klip A, Lee WL. 2015. Clathrin-dependent entry and vesicle-mediated exocytosis define insulin transcytosis across microvascular endothelial cells. Mol Biol Cell 26: $740-750$. 
Baker K, Qiao SW, Kuo T, Kobayashi K, Yoshida M, Lencer WI, Blumberg RS. 2009. Immune and non-immune functions of the (not so) neonatal Fc receptor, FcRn. Semin Immunopathol 31: 223-236.

Barroso M, Sztul ES. 1994. Basolateral to apical transcytosis in polarized cells is indirect and involves BFA and trimeric $\mathrm{G}$ protein sensitive passage through the apical endosome. J Cell Biol 124: 83-100.

Bay AE, Schreiner R, Rodriguez-Boulan E. 2015. Structural and functional analysis of endosomal compartments in epithelial cells. Methods Cell Biol 130: 271-288.

Ben-Zvi A, Lacoste B, Kur E, Andreone BJ, Mayshar Y, Yan H, Gu C. 2014. Mfsd2a is critical for the formation and function of the blood-brain barrier. Nature 509: 507511.

Bian F, Yang X, Zhou F, Wu PH, Xing S, Xu G, Li W, Chi J, Ouyang C, Zhang Y, et al. 2014. C-reactive protein promotes atherosclerosis by increasing LDL transcytosis across endothelial cells. Br J Pharmacol 171: 2671-2684.

Bomsel M. 1997. Transcytosis of infectious human immunodeficiency virus across a tight human epithelial cell line barrier. Nat Med 3: 42-47.

Bomsel M, Prydz K, Parton RG, Gruenberg J, Simons K. 1989. Endocytosis in filter-grown Madin-Darby canine kidney cells. J Cell Biol 109: 3242-3258.

Bomsel M, Parton R, Kuznetsov SA, Schroer TA, Gruenberg J. 1990. Microtubule- and motor-dependent fusion in vitro between apical and basolateral endocytic vesicles from MDCK cells. Cell 62: 719-731.

Bonifacino JS, Rojas R. 2006. Retrograde transport from endosomes to the trans-Golgi network. Nat Rev Mol Cell Biol 7: 568-579.

Brandli AW, Adamson ED, Simons K. 1991. Transcytosis of epidermal growth factor. The epidermal growth factor receptor mediates uptake but not transcytosis. J Biol Chem 266: 8560-8566.

Breitfeld PP, Harris JM, Mostov KE. 1989. Postendocytic sorting of the ligand for the polymeric immunoglobulin receptor in Madin-Darby canine kidney cells. J Cell Biol 109: $475-476$.

Breitfield PP, McKinnon WC, Mostov KE. 1990. Effect of nocodazole on vesicular traffic to the apical and basolateral surfaces of polarized MDCK cells. J Cell Biol 111: 2365-2373.

Broadwell RD, Baker-Cairns BJ, Friden PM, Oliver C, Villegas JC. 1996. Transcytosis of protein through the mammalian cerebral epithelium and endothelium. III: Receptor-mediated transcytosis through the blood-brain barrier of blood-borne transferrin and antibody against the transferrin receptor. Exp Neurol 142: 47-65.

Brown PS, Wang E, Aroeti B, Chapin SJ, Mostov KE, Dunn KW. 2000. Definition of distinct compartments in polarized Madin-Darby canine kidney (MDCK) cells for membrane-volume sorting, polarized sorting and apical recycling. Traffic (Copenhagen, Denmark) 1: 124-140.

Bryant DM, Datta A, Rodriguez-Fraticelli AE, Peranen J, Martin-Belmonte F, Mostov KE. 2010. A molecular network for de novo generation of the apical surface and lumen. Nat Cell Biol 12: 1035-1045.

Bryant DM, Roignot J, Datta A, Overeem AW, Kim M, Yu W, Peng X, Eastburn DJ, Ewald AJ, Werb Z, et al. 2014. A
Membrane Transport across Polarized Epithelia

molecular switch for the orientation of epithelial cell polarization. Dev Cell 31: 171-187.

Burdo JR, Antonetti DA, Wolpert EB, Connor JR. 2003. Mechanisms and regulation of transferrin and iron transport in a model blood-brain barrier system. Neuroscience 121: $883-890$.

Callan-Jones A, Sorre B, Bassereau P. 2011. Curvature-driven lipid sorting in biomembranes. Cold Spring Harb Perspect Biol 3: a004648.

Candela P, Gosselet F, Miller F, Buee-Scherrer V, Torpier G, Cecchelli R, Fenart L. 2008. Physiological pathway for low-density lipoproteins across the blood-brain barrier: Transcytosis through brain capillary endothelial cells in vitro. Endothelium 15: 254-264.

Casanova JE, Wang X, Kumar R, Bhartur SG, Navarre J, Woodrum JE, Altschuler Y, Ray GS, Goldenring JR. 1999. Association of Rab25 and Rab1la with the apical recycling system of polarized Madin-Darby canine kidney cells. Mol Biol Cell 10: 47-61.

Chinnapen DJ, Hsieh WT, te Welscher YM, Saslowsky DE, Kaoutzani L, Brandsma E, D’Auria L, Park H, Wagner JS, Drake KR, et al. 2012. Lipid sorting by ceramide structure from plasma membrane to ER for the cholera toxin receptor Ganglioside GM1. Dev Cell 23: 573-586.

Claypool SM, Dickinson BL, Yoshida M, Lencer WI, Blumberg RS. 2002. Functional reconstitution of human FcRn in Madin-Darby canine kidney cells requires coexpressed human $\beta 2$-microglobulin. J Biol Chem 277: 28038-28050.

Couesnon A, Pereira Y, Popoff MR. 2008. Receptor-mediated transcytosis of botulinum neurotoxin A through intestinal cell monolayers. Cell Microbiol 10: 375-387.

Cuartero Y, Mellado M, Capell A, Alvarez-Dolado M, Verges M. 2012. Retromer regulates postendocytic sorting of $\beta$ secretase in polarized Madin-Darby canine kidney cells. Traffic 13: 1393-1410.

de Marco MC, Martín-Belmonte F, Kremer L, Albar JP, Correas I, Vaerman JP, Marazuela M, Byrne JA, Alonso MA 2002. MAL2, a novel raft protein of the MAL family, is an essential component of the machinery for transcytosis in hepatoma HepG2 cells. J Cell Biol 159: 37-44.

de Marco MC, Puertollano R, Martinez-Menarguez JA, Alonso MA. 2006. Dynamics of MAL2 during glycosylphosphatidylinositol-anchored protein transcytotic transport to the apical surface of hepatoma HepG2 cells. Traffic 7: 61-73.

Descamps L, Dehouck MP, Torpier G, Cecchelli R. 1996. Receptor-mediated transcytosis of transferrin through blood-brain barrier endothelial cells. Am J Physiol 270: H1149-H1158.

Diaz-Rohrer B, Levental KR, Levental I. 2014. Rafting through traffic: Membrane domains in cellular logistics. Biochim Biophys Acta 1838: 3003-3013.

Dohgu S, Fleegal-DeMotta MA, Banks WA. 2011. Lipopolysaccharide-enhanced transcellular transport of HIV-1 across the blood-brain barrier is mediated by luminal microvessel IL-6 and GM-CSF. J Neuroinflammation 8: 167.

Du W, Fan Y, Zheng N, He B, Yuan L, Zhang H, Wang X, Wang J, Zhang X, Zhang Q. 2013. Transferrin receptor specific nanocarriers conjugated with functional 7 peptide for oral drug delivery. Biomaterials 34: 794-806. 
M.D. Garcia-Castillo et al.

Ducharme NA, Williams JA, Oztan A, Apodaca G, Lapierre LA, Goldenring JR. 2007. Rab11-FIP2 regulates differentiable steps in transcytosis. Am J Physiol Cell Physiol 293: C1059-C1072.

Ducharme NA, Ham AJL, Lapierre LA, Goldenring JR. 2011. Rab11-FIP2 influences multiple components of the endosomal system in polarized MDCK cells. Cell Logist 1: 57-68.

Fajka-Boja R, Blasko A, Kovacs-Solyom F, Szebeni GJ, Toth GK, Monostori E. 2008. Colocalization of galectin-1 with GM1 ganglioside in the course of its clathrin- and raftdependent endocytosis. Cell Mol Life Sci 65: 2586-2593.

Fan W, Xia D, Zhu Q, Hu L, Gan Y. 2016. Intracellular transport of nanocarriers across the intestinal epithelium. Drug Discov Today 21: 856-863.

Fishman JB, Rubin JB, Handrahan JV, Connor JR, Fine RE. 1987. Receptor-mediated transcytosis of transferrin across the blood-brain barrier. J Neurosci Res 18: 299304.

Folsch H. 2008. Regulation of membrane trafficking in polarized epithelial cells. Curr Opin Cell Biol 20: 208-213.

Folsch H. 2015. Analyzing the role of AP-1B in polarized sorting from recycling endosomes in epithelial cells. Methods Cell Biol 130: 289-305.

Folsch H, Ohno H, Bonifacino JS, Mellman I. 1999. A novel clathrin adaptor complex mediates basolateral targeting in polarized epithelial cells. Cell 99: 189-198.

Folsch H, Mattila PE, Weisz OA. 2009. Taking the scenic route: Biosynthetic traffic to the plasma membrane in polarized epithelial cells. Traffic 10: 972-981.

Forte JG, Hanzel DK, Okamoto C, Chow D, Urushidani T. 1990. Membrane and protein recycling associated with gastric $\mathrm{HCl}$ secretion. J Intern Med Suppl 732: 17-26.

Gallo LI, Liao Y, Ruiz WG, Clayton DR, Li M, Liu YJ, Jiang Y, Fukuda M, Apodaca G, Yin XM. 2014. TBC1D9B functions as a GTPase-activating protein for Rab1 la in polarized MDCK cells. Mol Biol Cell 25: 3779-3797.

Galmes R, Delaunay JL, Maurice M, Ait-Slimane T. 2013. Oligomerization is required for normal endocytosis/ transcytosis of a GPI-anchored protein in polarized hepatic cells. J Cell Sci 126: 3409-3416.

Gan Y, McGraw TE, Rodriguez-Boulan E. 2002. The epithelial-specific adaptor AP1B mediates post-endocytic recycling to the basolateral membrane. Nat Cell Biol 4: 605609.

Georgieva JV, Hoekstra D, Zuhorn IS. 2014. Smuggling drugs into the brain: An overview of ligands targeting transcytosis for drug delivery across the blood-brain barrier. Pharmaceutics 6: 557-583.

Gibson A, Futter CE, Maxwell S, Allchin EH, Shipman M, Kraehenbuhl JP, Domingo D, Odorizzi G, Trowbridge IS, Hopkins CR. 1998. Sorting mechanisms regulating membrane protein traffic in the apical transcytotic pathway of polarized MDCK cells. J Cell Biol 143: 81-94.

Goldenring JR. 2015. Recycling endosomes. Curr Opin Cell Biol 35: 117-122.

Goldenring JR, Smith J, Vaughan HD, Cameron P, Hawkins W, Navarre J. 1996. Rab11 is an apically located small GTP-binding protein in epithelial tissues. Am J Physiol 270: G515-G525.
Gonzalez A, Rodriguez-Boulan E. 2009. Clathrin and AP1B: Key roles in basolateral trafficking through trans-endosomal routes. FEBS Lett 583: 3784-3795.

Gravotta D, Deora A, Perret E, Oyanadel C, Soza A, Schreiner R, Gonzalez A, Rodriguez-Boulan E. 2007. AP1B sorts basolateral proteins in recycling and biosynthetic routes of MDCK cells. Proc Natl Acad Sci 104: $1564-1569$.

Guemez-Gamboa A, Nguyen LN, Yang H, Zaki MS, Kara M, Ben-Omran T, Akizu N, Rosti RO, Rosti B, Scott E, et al. 2015. Inactivating mutations in MFSD2A, required for omega-3 fatty acid transport in brain, cause a lethal microcephaly syndrome. Nat Genet 47: 809-813.

Gupta S, Gach JS, Becerra JC, Phan TB, Pudney J, Moldoveanu Z, Joseph SB, Landucci G, Supnet MJ, Ping LH, et al. 2013. The neonatal Fc receptor ( FcRn) enhances human immunodeficiency virus Type 1 (HIV-1) transcytosis across epithelial cells. PLoS Pathog 9: e1003776.

Heinrich M, Tian A, Esposito C, Baumgart T. 2010. Dynamic sorting of lipids and proteins in membrane tubes with a moving phase boundary. Proc Natl Acad Sci 107: 72087213.

Hoekstra D, Tyteca D, van ISC. 2004. The subapical compartment: A traffic center in membrane polarity development. J Cell Sci 117: 2183-2192.

Honig E, Schneider K, Jacob R. 2015. Recycling of galectin-3 in epithelial cells. Eur J Cell Biol 94: 309-315.

Hoppe CA, Connolly TP, Hubbard AL. 1985. Transcellular transport of polymeric IgA in the rat hepatocyte: Biochemical and morphological characterization of the transport pathway. J Cell Biol 101: 2113-2123.

Huber LA, Fialka I, Paiha K, Hunziker W, Sacks DB, Bahler M, Way M, Gagescu R, Gruenberg J. 2000. Both calmodulin and the unconventional myosin Myr4 regulate membrane trafficking along the recycling pathway of MDCK cells. Traffic 1: 494-503.

Hughson EJ, Hopkins CR. 1990. Endocytic pathways in polarized Caco-2 cells: Identification of an endosomal compartment accessible from both apical and basolateral surfaces. J Cell Biol 110: 337-348.

Hunziker W, Male P, Mellman I. 1990. Differential microtubule requirements for transcytosis in MDCK cells. EMBO J 9: 3515-3525.

Hyman T, Shmuel M, Altschuler Y. 2006. Actin is required for endocytosis at the apical surface of Madin-Darby canine kidney cells where ARF6 and clathrin regulate the actin cytoskeleton. Mol Biol Cell 17: 427-437.

In JG, Tuma PL. 2010. MAL2 selectively regulates polymeric IgA receptor delivery from the Golgi to the plasma membrane in WIF-B cells. Traffic 11: 1056-1066.

Jaulin F, Xue X, Rodriguez-Boulan E, Kreitzer G. 2007. Polarization-dependent selective transport to the apical membrane by KIF5B in MDCK cells. Dev Cell 13: 511522.

Johannessen LE, Spilsberg B, Wiik-Nielsen CR, Kristoffersen AB, Holst-Jensen A, Berdal KG. 2013. DNA-fragments are transcytosed across $\mathrm{CaCo}-2$ cells by adsorptive endocytosis and vesicular mediated transport. PloS ONE 8: e56671.

Juliano RL. 2016. The delivery of therapeutic oligonucleotides. Nucleic Acids Res doi: 10.1093/nar/gkw236. 
Karve SS, Weiss AA. 2014. Glycolipid binding preferences of Shiga toxin variants. PLoS ONE 9: e101173.

Kinlock BL, Wang Y, Turner TM, Wang C, Liu B. 2014. Transcytosis of HIV-1 through vaginal epithelial cells is dependent on trafficking to the endocytic recycling pathway. PLoS ONE 9: e96760.

Klinger SC, Hojland A, Jain S, Kjolby M, Madsen P, Svendsen AD, Olivecrona G, Bonifacino JS, Nielsen MS. 2016. Polarized trafficking of the sorting receptor SorLA in neurons and MDCK cells. FEBS J 283: 2476-3493.

Kozu A, Kato Y, Shitara Y, Hanano M, Sugiyama Y. 1997. Kinetic analysis of transcytosis of epidermal growth factor in Madin-Darby canine kidney epithelial cells. Pharm Res 14: 1228-1235.

Kuebler WM, Wittenberg C, Lee WL, Reppien E, Goldenberg NM, Lindner K, Gao Y, Winoto-Morbach S, Drab M, Muhlfeld C, et al. 2016. Thrombin stimulates albumin transcytosis in lung microvascular endothelial cells via activation of acid sphingomyelinase. Am J Physiol Lung Cell Mol Physiol 310: L720-L732.

Lajoie JM, Shusta EV. 2015. Targeting receptor-mediated transport for delivery of biologics across the blood-brain barrier. Annu Rev Pharmacol Toxicol 55: 613-631.

Lakshminarayan R, Wunder C, Becken U, Howes MT, Benzing C, Arumugam S, Sales S, Ariotti N, Chambon V, Lamaze C, et al. 2014. Galectin-3 drives glycosphingolipid-dependent biogenesis of clathrin-independent carriers. Nat Cell Biol 16: 595-606.

Lapierre LA, Goldenring JR. 2005. Interactions of myosin vb with rab11 family members and cargoes traversing the plasma membrane recycling system. Methods Enzymol 403: $715-723$.

Lapierre LA, Kumar R, Hales CM, Navarre J, Bhartur SG, Burnette JO, Provance DW Jr, Mercer JA, Bahler M, Goldenring JR. 2001. Myosin vb is associated with plasma membrane recycling systems. Mol Biol Cell 12: $1843-$ 1857.

Lapierre LA, Avant KM, Caldwell CM, Oztan A, Apodaca G, Knowles BC, Roland JT, Ducharme NA, Goldenring JR. 2012. Phosphorylation of Rab11-FIP2 regulates polarity in MDCK cells. Mol Biol Cell 23: 2302-2318.

Lee JS, Frevert CW, Wurfel MM, Peiper SC, Wong VA, Ballman KK, Ruzinski JT, Rhim JS, Martin TR, Goodman RB. 2003. Duffy antigen facilitates movement of chemokine across the endothelium in vitro and promotes neutrophil transmigration in vitro and in vivo. J Immunol 170: 5244-5251.

Lencer WI, Moe S, Rufo PA, Madara JL. 1995. Transcytosis of cholera toxin subunits across model human intestinal epithelia. Proc Natl Acad Sci 92: 10094-10098.

Leung SM, Ruiz WG, Apodaca G. 2000. Sorting of membrane and fluid at the apical pole of polarized MadinDarby canine kidney cells. Mol Biol Cell 11: 2131-2150.

Li C, Hao M, Cao Z, Ding W, Graves-Deal R, Hu J, Piston DW, Coffey RJ. 2007. Naked2 acts as a cargo recognition and targeting protein to ensure proper delivery and fusion of TGF- $\alpha$ containing exocytic vesicles at the lower lateral membrane of polarized MDCK cells. Mol Biol Cell 18: 3081-3093.

Li Z, Palaniyandi S, Zeng R, Tuo W, Roopenian DC, Zhu X. 2011. Transfer of IgG in the female genital tract by MHC class I-related neonatal Fc receptor (FcRn) confers pro- tective immunity to vaginal infection. Proc Natl Acad Sci 108: $4388-4393$.

Li W, Yang X, Xing S, Bian F, Yao W, Bai X, Zheng T, Wu G, Jin S. 2014. Endogenous ceramide contributes to the transcytosis of oxLDL across endothelial cells and promotes its subendothelial retention in vascular wall. Oxid Med Cell Longev doi: 10.1155/2014/823071.

Lock JG, Stow JL. 2005. Rab11 in recycling endosomes regulates the sorting and basolateral transport of E-cadherin. Mol Biol Cell 16: 1744-1755.

Lockett AD, Brown MB, Santos-Falcon N, Rush NI, Oueini H, Oberle AJ, Bolanis E, Fragoso MA, Petrusca DN, Serban KA, et al. 2014. Active trafficking of $\alpha 1$ antitrypsin across the lung endothelium. PLoS ONE 9: e93979.

Lukyanenko V, Malyukova I, Hubbard A, Delannoy M, Boedeker E, Zhu C, Cebotaru L, Kovbasnjuk O. 2011. Enterohemorrhagic Escherichia coli infection stimulates Shiga toxin 1 macropinocytosis and transcytosis across intestinal epithelial cells. Am J Physiol Cell Physiol 301: C1140C1149.

Madrid R, Aranda JF, Rodriguez-Fraticelli AE, Ventimiglia L, Andres-Delgado L, Shehata M, Fanayan S, Shahheydari H, Gomez S, Jimenez A, et al. 2010. The formin INF2 regulates basolateral-to-apical transcytosis and lumen formation in association with Cdc42 and MAL2. Dev Cell 18: 814-827.

Magal LG, Yaffe Y, Shepshelovich J, Aranda JF, de Marco Mdel C, Gaus K, Alonso MA, Hirschberg K. 2009. Clustering and lateral concentration of raft lipids by the MAL protein. Mol Biol Cell 20: 3751-3762.

Maksymowych AB, Simpson LL. 1998. Binding and transcytosis of Botulinum neurotoxin by polarized human colon carcinoma cells. J Biol Chem 273: 21950-21957.

Malyukova I, Gutsal O, Laiko M, Kane A, Donowitz M, Kovbasnjuk O. 2008. Latrunculin B facilitates Shiga toxin 1 transcellular transcytosis across T84 intestinal epithelial cells. Biochim Biophys Acta 1782: 370-377.

Malyukova I, Murray KF, Zhu C, Boedeker E, Kane A, Patterson K, Peterson JR, Donowitz M, Kovbasnjuk O. 2009. Macropinocytosis in Shiga toxin 1 uptake by human intestinal epithelial cells and transcellular transcytosis. Am J Physiol Gastro Liver Physiol 296: G78-G92.

Manich G, Cabezón I, del Valle J, Duran-Vilaregut J, Camins A, Pallàs M, Pelegrí C, Vilaplana J. 2013. Study of the transcytosis of an anti-transferrin receptor antibody with a Fab' cargo across the blood-brain barrier in mice. Eur J. Pharmaceutical Sci 49: 556-564.

Maratos-Flier E, Kao CY, Verdin EM, King GL. 1987. Receptor-mediated vectorial transcytosis of epidermal growth factor by Madin-Darby canine kidney cells. J Cell Biol 105: $1595-1601$.

Marazuela M, Martín-Belmonte F, García-López MA, Aranda JF, de Marco MC, Alonso MA. 2004. Expression and distribution of MAL2, an essential element of the machinery for basolateral-to-apical transcytosis, in human thyroid epithelial cells. Endocrinology 145: 10111016.

Marsh EW, Leopold PL, Jones NL, Maxfield FR. 1995. Oligomerized transferrin receptors are selectively retained by a lumenal sorting signal in a long-lived endocytic recycling compartment. J Cell Biol 129: 1509-1522. 
M.D. Garcia-Castillo et al.

Martin-Latil S, Gnadig NF, Mallet A, Desdouits M, GuivelBenhassine F, Jeannin P, Prevost M-C, Schwartz O, Gessain A, Ozden S, et al. 2012. Transcytosis of HTLV-1 across a tight human epithelial barrier and infection of subepithelial dendritic cells. Blood 120: $572-580$.

Martins JP, Kennedy PJ, Santos HA, Barrias C, Sarmento B. 2016. A comprehensive review of the neonatal $\mathrm{Fc}$ receptor and its application in drug delivery. Pharmacol Therapeut 161: 22-39.

Maxfield FR, McGraw TE. 2004. Endocytic recycling. Nat Rev Mol Cell Biol 5: 121-132.

Mayor S, Parton RG, Donaldson JG. 2014. Clathrin-independent pathways of endocytosis. Cold Spring Harb Perspect Biol 6: a016758.

Mellman I. 1996. Endocytosis and molecular sorting. Annu Rev Cell Dev Biol 12: 575-625.

Minten C, Alt C, Gentner M, Frei E, Deutsch U, Lyck R, Schaeren-Wiemers N, Rot A, Engelhardt B. 2014. DARC shuttles inflammatory chemokines across the bloodbrain barrier during autoimmune central nervous system inflammation. Brain 137: 1454-1469.

Miyashita SI, Niwa K, Watanabe T, Sagane Y. 2014. Host-cell specificity and transcytosis of nontoxic nonhemagglutinin protein of botulinum neurotoxin serotype D. FEMS Microbiol Lett 357: 115-122.

Moon C, VanDussen KL, Miyoshi H, Stappenbeck TS. 2014. Development of a primary mouse intestinal epithelial cell monolayer culture system to evaluate factors that modulate IgA transcytosis. Mucosal Immunol 7: 818-828.

Mostov KE. 1994. Transepithelial transport of immunoglobulins. Annu Rev Immunol 12: 63-84.

Mostov KE, Verges M, Altschuler Y. 2000. Membrane traffic in polarized epithelial cells. Curr Opin Cell Biol 12: 483490.

Mrozowska PS, Fukuda M. 2016. Regulation of podocalyxin trafficking by Rab small GTPases in 2D and 3D epithelial cell cultures. J Cell Biol 213: 355-369.

Muller T, Hess MW, Schiefermeier N, Pfaller K, Ebner HL, Heinz-Erian P, Ponstingl H, Partsch J, Rollinghoff B, Kohler H, et al. 2008. MYO5B mutations cause microvillus inclusion disease and disrupt epithelial cell polarity. Nat Genet 40: 1163-1165.

Nguyen LN, Ma D, Shui G, Wong P, Cazenave-Gassiot A, Zhang X, Wenk MR, Goh EL, Silver DL. 2014. Mfsd2a is a transporter for the essential omega-3 fatty acid docosahexaenoic acid. Nature 509: 503-506.

Niewoehner J, Bohrmann B, Collin L, Urich E, Sade H, Maier P, Rueger P, Stracke JO, Lau W, Tissot AC, et al. 2014. Increased brain penetration and potency of a therapeutic antibody using a monovalent molecular shuttle. Neuron 81: 49-60.

Nikitas G, Deschamps C, Disson O, Niault T, Cossart P, Lecuit M. 2011. Transcytosis of Listeria monocytogenes across the intestinal barrier upon specific targeting of goblet cell accessible E-cadherin. J Exp Med 208: $2263-$ 2277.

Novitzky-Basso I, Rot A. 2012. Duffy antigen receptor for chemokines and its involvement in patterning and control of inflammatory chemokines. Front Immunol 3: 266.

Odorizzi G, Pearse A, Domingo D, Trowbridge IS, Hopkins CR. 1996. Apical and basolateral endosomes of MDCK cells are interconnected and contain a polarized sorting mechanism. J Cell Biol 135: 139-152.

Palaniyandi S, Liu X, Periasamy S, Ma A, Tang J, Jenkins M, Tuo W, Song W, Keegan AD, Conrad DH, et al. 2015. Inhibition of CD23-mediated IgE transcytosis suppresses the initiation and development of allergic airway inflammation. Mucosal Immunol 8: 1262-1274.

Parakh S, Parslow AC, Gan HK, Scott AM. 2016. Antibodymediated delivery of therapeutics for cancer therapy. Exp Opin Drug Deliv 13: 401-419.

Pardridge WM. 2015. Targeted delivery of protein and gene medicines through the blood-brain barrier. Clin Pharmacol Therapeut 97: 347-361.

Parton RG, Prydz K, Bomsel M, Simons K, Griffiths G. 1989. Meeting of the apical and basolateral endocytic pathways of the Madin-Darby canine kidney cell in late endosomes. J Cell Biol 109: 3259-3272.

Perez Bay AE, Schreiner R, Mazzoni F, Carvajal-Gonzalez JM, Gravotta D, Perret E, Lehmann Mantaras G, Zhu YS, Rodriguez-Boulan EJ. 2013. The kinesin KIF16B mediates apical transcytosis of transferrin receptor in AP1B-deficient epithelia. EMBO J 32: 2125-2139.

Perez Bay AE, Schreiner R, Benedicto I, Rodriguez-Boulan EJ. 2014. Galectin-4-mediated transcytosis of transferrin receptor. J Cell Sci 127: 4457-4469.

Pocard T, Le Bivic A, Galli T, Zurzolo C. 2007. Distinct vSNAREs regulate direct and indirect apical delivery in polarized epithelial cells. J Cell Sci 120: 3309-3320.

Preston JE, Joan Abbott N, Begley DJ. 2014. Transcytosis of macromolecules at the blood-brain barrier. Adv Pharmacol 71: 147-163.

Pruenster M, Mudde L, Bombosi P, Dimitrova S, Zsak M, Middleton J, Richmond A, Graham GJ, Segerer S, Nibbs RJB, et al. 2009. The Duffy antigen receptor for chemokines transports chemokines and supports their promigratory activity. Nat Immunol 10: 101-108.

Pyzik M, Rath T, Lencer WI, Baker K, Blumberg RS. 2015. FcRn: The architect behind the immune and nonimmune functions of IgG and albumin. J Immunol 194: 4595-4603.

Rabideau AE, Pentelute BL. 2016. Delivery of non-native cargo into mammalian cells using anthrax lethal toxin. ACS Chem Biol 11: 1490-1501.

Ramnarayanan SP, Tuma PL. 2011. MAL, but not MAL2, expression promotes the formation of cholesterol-dependent membrane domains that recruit apical proteins. Biochem J 439: 497-504.

Rath T, Baker K, Pyzik M, Blumberg RS. 2014. Regulation of immune responses by the neonatal fc receptor and its therapeutic implications. Front Immunol 5: 664.

Roberts RL, Fine RE, Sandra A. 1993. Receptor-mediated endocytosis of transferrin at the blood-brain barrier. J Cell Sci 104: 521-532.

Rodriguez-Boulan E, Macara IG. 2014. Organization and execution of the epithelial polarity programme. Nat Rev Mol Cell Biol 15: 225-242.

Rojas R, Apodaca G. 2002. Immunoglobulin transport across polarized epithelial cells. Nat Rev Mol Cell Biol 3: 944-955.

Roland JT, Bryant DM, Datta A, Itzen A, Mostov KE, Goldenring JR. 2011. Rab GTPase-Myo5B complexes control 
membrane recycling and epithelial polarization. Proc Natl Acad Sci 108: 2789-2794.

Saslowsky DE, te Welscher YM, Chinnapen DJ, Wagner JS, Wan J, Kern E, Lencer WI. 2013. Ganglioside GM1-mediated transcytosis of cholera toxin bypasses the retrograde pathway and depends on the structure of the ceramide domain. J Biol Chem 288: 25804-25809.

Schuck S, Simons K. 2004. Polarized sorting in epithelial cells: Raft clustering and the biogenesis of the apical membrane. J Cell Sci 117: 5955-5964.

Sheff DR, Daro EA, Hull M, Mellman I. 1999. The receptor recycling pathway contains two distinct populations of early endosomes with different sorting functions. J Cell Biol 145: 123-139.

Sheff DR, Kroschewski R, Mellman I. 2002. Actin dependence of polarized receptor recycling in Madin-Darby canine kidney cell endosomes. Mol Biol Cell 13:262-275.

Shmuel M, Santy LC, Frank S, Avrahami D, Casanova JE, Altschuler Y. 2006. ARNO through its coiled-coil domain regulates endocytosis at the apical surface of polarized epithelial cells. J Biol Chem 281: 13300-13308.

Shultz T, Nash-Livni N, Shmuel M, Altschuler Y. 2006. EFA6 regulates endosomal trafficking and affects early endosomes in polarized MDCK cells. Biochem Biophys Res Commun 351: 106-112.

Simionescu M, Simionescu N. 1991. Endothelial transport of macromolecules: Transcytosis and endocytosis. A look from cell biology. Cell Biol Rev 25: 1-78.

Simionescu M, Gafencu A, Antohe F. 2002. Transcytosis of plasma macromolecules in endothelial cells: A cell biological survey. Microsc Res Tech 57: 269-288.

Skarlatos S, Yoshikawa T, Pardridge WM. 1995. Transport of $\left[{ }^{125} \mathrm{I}\right]$ transferrin through the rat blood-brain barrier. Brain Res 683: 164-171.

Sonnichsen B, De Renzis S, Nielsen E, Rietdorf J, Zerial M. 2000. Distinct membrane domains on endosomes in the recycling pathway visualized by multicolor imaging of Rab4, Rab5, and Rab11. J Cell Biol 149: 901-914.

Spiekermann GM, Finn PW, Ward ES, Dumont J, Dickinson BL, Blumberg RS, Lencer WI. 2002. Receptor-mediated immunoglobulin $\mathrm{G}$ transport across mucosal barriers in adult life: Functional expression of FcRn in the mammalian lung. J Exp Med 196: 303-310.

Stojanov K, Georgieva JV, Brinkhuis RP, van Hest JC, Rutjes FP, Dierckx RA, de Vries EF, Zuhorn IS. 2012. In vivo biodistribution of prion- and GM1-targeted polymersomes following intravenous administration in mice. Mol Pharm 9: 1620-1627.

Stratmann T. 2015. Cholera toxin subunit B as adjuvantAn accelerator in protective immunity and a break in autoimmunity. Vaccines 3: 579-596.

Striz AC, Tuma PL. 2016. The GTP-bound and sumoylated form of the rab17 small molecular weight GTPase selectively binds syntaxin 2 in polarized hepatic WIF-B cells. J Biol Chem 291: 9721-9732.

Su T, Bryant DM, Luton F, Verges M, Ulrich SM, Hansen KC, Datta A, Eastburn DJ, Burlingame AL, Shokat KM, et al. 2010. A kinase cascade leading to Rab11-FIP5 controls transcytosis of the polymeric immunoglobulin receptor. Nat Cell Biol 12: 1143-1153.
Membrane Transport across Polarized Epithelia

Swiatecka-Urban A, Talebian L, Kanno E, Moreau-Marquis S, Coutermarsh B, Hansen K, Karlson KH, Barnaby R, Cheney RE, Langford GM, et al. 2007. Myosin Vb is required for trafficking of the cystic fibrosis transmembrane conductance regulator in Rablla-specific apical recycling endosomes in polarized human airway epithelial cells. J Biol Chem 282: 23725-23736.

Tajika Y, Matsuzaki T, Suzuki T, Aoki T, Hagiwara H, Kuwahara M, Sasaki S, Takata K. 2004. Aquaporin-2 is retrieved to the apical storage compartment via early endosomes and phosphatidylinositol 3-kinase-dependent pathway. Endocrinology 145: 4375-4383.

Tang Y, Han T, Everts M, Zhu ZB, Gillespie GY, Curiel DT, Wu H. 2007. Directing adenovirus across the bloodbrain barrier via melanotransferrin (P97) transcytosis pathway in an in vitro model. Gene Ther 14: 523-532.

Tanigaki K, Chambliss KL, Yuhanna IS, Sacharidou A, Ahmed M, Atochin DN, Huang PL, Shaul PW, Mineo C. 2016. Endothelial Fcy receptor IIB activation blunts insulin delivery to skeletal muscle to cause insulin resistance in mice. Diabetes 65: 1996-2005.

Tanos B, Rodriguez-Boulan E. 2008. The epithelial polarity program: Machineries involved and their hijacking by cancer. Oncogene 27: 6939-6957.

te Welscher YM, Chinnapen DJ, Kaoutzani L, Mrsny RJ, Lencer WI. 2014. Unsaturated glycoceramides as molecular carriers for mucosal drug delivery of GLP-1.J Control Release 175: 72-78.

Thompson A, Nessler R, Wisco D, Anderson E, Winckler B, Sheff D. 2007. Recycling endosomes of polarized epithelial cells actively sort apical and basolateral cargos into separate subdomains. Mol Biol Cell 18: 2687-2697.

Tugizov SM, Herrera R, Palefsky JM. 2013. Epstein-Barr virus transcytosis through polarized oral epithelial cells. J Virol 87: 8179-8194.

Tuma PL, Hubbard AL. 2003. Transcytosis: Crossing cellular barriers. Physiol Rev 83: 871-932.

Tzaban S, Massol RH, Yen E, Hamman W, Frank SR, Lapierre LA, Hansen SH, Goldenring JR, Blumberg RS, Lencer WI. 2009. The recycling and transcytotic pathways for IgG transport by FcRn are distinct and display an inherent polarity. J Cell Biol 185: 673-684.

van Ijzendoorn SC. 2006. Recycling endosomes. J Cell Sci 119: $1679-1681$.

van Ijzendoorn SCD, Hoekstra D. 1999. The subapical compartment: A novel sorting center? Trend Cel Biol 9: 144149.

Verges M. 2016. Retromer in polarized protein transport. Int Rev Cell Mol Biol 323: 129-179.

Verges M, Luton F, Gruber C, Tiemann F, Reinders LG, Huang L, Burlingame AL, Haft CR, Mostov KE. 2004. The mammalian retromer regulates transcytosis of the polymeric immunoglobulin receptor. Nat Cell Biol 6: $763-769$.

Verges M, Sebastian I, Mostov KE. 2007. Phosphoinositide 3-kinase regulates the role of retromer in transcytosis of the polymeric immunoglobulin receptor. Exp Cell Res 313: $707-718$.

Wakabayashi Y, Dutt P, Lippincott-Schwartz J, Arias IM. 2005. Rab1la and myosin $\mathrm{Vb}$ are required for bile cana- 
M.D. Garcia-Castillo et al.

licular formation in WIF-B9 cells. Proc Natl Acad Sci 102: 15087-15092.

Wang E, Brown PS, Aroeti B, Chapin SJ, Mostov KE, Dunn KW. 2000a. Apical and basolateral endocytic pathways of MDCK cells meet in acidic common endosomes distinct from a nearly-neutral apical recycling endosome. Traffic 1: $480-493$.

Wang X, Kumar R, Navarre J, Casanova JE, Goldenring JR. 2000b. Regulation of vesicle trafficking in Madin-Darby canine kidney cells by Rab1la and Rab25. J Biol Chem 275: 29138-29146.

Wang JZ, Xiao N, Zhang YZ, Zhao CX, Guo XH, Lu LM, et al. 2016. Mfsd2a-based pharmacological strategies for drug delivery across the blood-brain barrier. Pharmacol Res 104: 124-131.

Weisz OA, Rodriguez-Boulan E. 2009. Apical trafficking in epithelial cells: Signals, clusters and motors. J Cell Sci 122: 4253-4266.

Wiley DT, Webster P, Gale A, Davis ME. 2013. Transcytosis and brain uptake of transferrin-containing nanoparticles by tuning avidity to transferrin receptor. Proc Natl Acad Sci 110: 8662-8667.

Xu S, Edman M, Kothawala MS, Sun G, Chiang L, Mircheff A, Zhu L, Okamoto C, Hamm-Alvarez S. 2011. A Rablla-enriched subapical membrane compartment regulates a cytoskeleton-dependent transcytotic pathway in secretory epithelial cells of the lacrimal gland. J Cell Sci 124: 3503-3514.

Yamazaki Y, Palmer L, Alexandre C, Kakugawa S, Beckett K, Gaugue I, Palmer RH, Vincent JP. 2016. Godzilladependent transcytosis promotes Wingless signalling in
Drosophila wing imaginal discs. Nat Cell Biol 18: 451457.

Yasuda T, Saegusa C, Kamakura S, Sumimoto H, Fukuda M. 2012. Rab27 effector Slp2-a transports the apical signaling molecule podocalyxin to the apical surface of MDCK II cells and regulates claudin-2 expression. Mol Biol Cell 23: 3229-3239.

Yin X, Murphy SJ, Wilkes MC, Ji Y, Leof EB. 2013. Retromer maintains basolateral distribution of the type II TGF- $\beta$ receptor via the recycling endosome. Mol Biol Cell 24: 2285-2298.

Yu M, Yang Y, Zhu C, Guo S, Gan Y. 2016. Advances in the transepithelial transport of nanoparticles. Drug Discov Today 21: 1155-1161.

Yui N, Lu HAJ, Chen Y, Nomura N, Bouley R, Brown D. 2013. Basolateral targeting and microtubule-dependent transcytosis of the aquaporin-2 water channel. Am J Physiol Cell Physiology 304: C38-C48.

Zhang Y, Yang X, Bian F, Wu P, Xing S, Xu G, Li W, Chi J, Ouyang C, Zheng T, et al. 2014. TNF- $\alpha$ promotes early atherosclerosis by increasing transcytosis of LDL across endothelial cells: Crosstalk between NF- $\mathrm{KB}$ and PPAR- $\gamma$. J Mol Cell Cardiol 72: 85-94.

Zhao Z, Sagare AP, Ma Q, Halliday MR, Kong P, Kisler K, Winkler EA, Ramanathan A, Kanekiyo T, Bu G, et al. 2015. Central role for PICALM in amyloid- $\beta$ bloodbrain barrier transcytosis and clearance. Nat Neurosci 18: $978-987$.

Zhou K, Sumigray KD, Lechler T. 2015. The Arp2/3 complex has essential roles in vesicle trafficking and transcytosis in the mammalian small intestine. Mol Biol Cell 26: 1995-2004. 


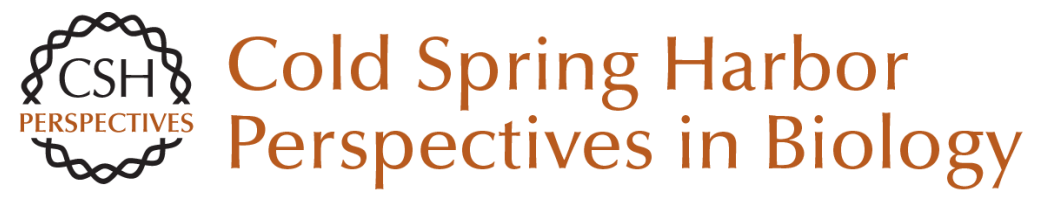

\title{
Membrane Transport across Polarized Epithelia
}

\author{
Maria Daniela Garcia-Castillo, Daniel J.-F. Chinnapen and Wayne I. Lencer
}

Cold Spring Harb Perspect Biol 2017; doi: 10.1101/cshperspect.a027912 originally published online February 17, 2017

\section{Subject Collection Cell Polarity}

Regulation of Cell Polarity by Exocyst-Mediated Trafficking Noemi Polgar and Ben Fogelgren

Phosphoinositides and Membrane Targeting in Cell Polarity Gerald R. Hammond and Yang Hong

Trafficking lon Transporters to the Apical Membrane of Polarized Intestinal Enterocytes Amy Christine Engevik and James R. Goldenring

Signaling Networks in Epithelial Tube Formation Ilenia Bernascone, Mariam Hachimi and Fernando Martin-Belmonte

Making Heads or Tails of It: Cell-Cell Adhesion in Cellular and Supracellular Polarity in Collective Migration Jan-Hendrik Venhuizen and Mirjam M. Zegers

Laminins in Epithelial Cell Polarization: Old Questions in Search of New Answers Karl S. Matlin, Satu-Marja Myllymäki and Aki Manninen

Epithelial Morphogenesis during Liver Development

Naoki Tanimizu and Toshihiro Mitaka

Targeting the Mucosal Barrier: How Pathogens Modulate the Cellular Polarity Network Travis R. Ruch and Joanne N. Engel
The Crumbs3 Polarity Protein Ben Margolis

Microtubule Motors in Establishment of Epithelial Cell Polarity Geri Kreitzer and Monn Monn Myat

Role of Polarity Proteins in the Generation and Organization of Apical Surface Protrusions Gerard Apodaca

Polarized Exocytosis Jingwen Zeng, Shanshan Feng, Bin Wu, et al.

Regulation of Transporters and Channels by Membrane-Trafficking Complexes in Epithelial Cells

Curtis T. Okamoto

Membrane Transport across Polarized Epithelia Maria Daniela Garcia-Castillo, Daniel J.-F. Chinnapen and Wayne I. Lencer

Mechanisms of Cell Polarity-Controlled Epithelial Homeostasis and Immunity in the Intestine Leon J. Klunder, Klaas Nico Faber, Gerard Dijkstra, et al.

The Biology of Ciliary Dynamics Kuo-Shun Hsu, Jen-Zen Chuang and Ching-Hwa Sung

For additional articles in this collection, see http://cshperspectives.cshlp.org/cgi/collection/

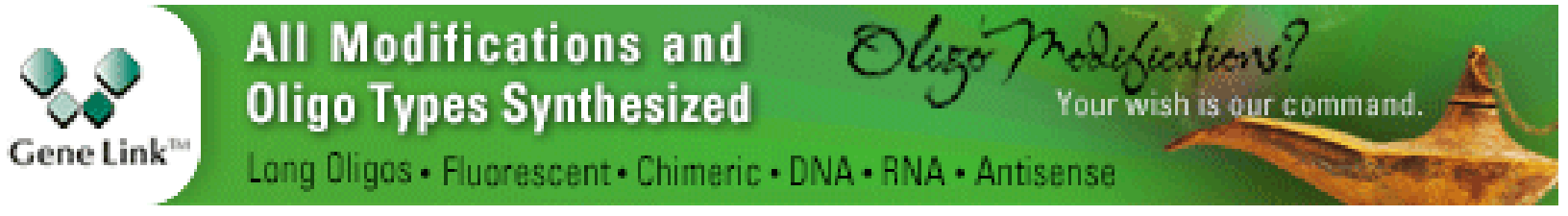

